\title{
ANALISIS KETERAMPILAN BERTANYA SISWA MATA PELAJARAN TEMATIK TEMA 8 SUBTEMA 3 KELAS V SDN 2 MOJOARUM
}

\author{
Anik Rahayuningsih ${ }^{1}$, Nugrananda Janattaka ${ }^{2}$, \\ ${ }^{12}$ STKIP PGRI Tulungagung \\ Eanikrahayuningsih4@gmail.com
}

\begin{abstract}
Question and answer is a major part of student learning activities. The questioning activity is asking factual questions or hypotheses that begin with guidance from the teacher until students understand themselves and become habitual activities. This study aims to describe the Students' Asking Skills in the Environment is the theme of Our Friends Sub Thematic Environmental Conservation Sub-Thematic Subjects and describe the obstacles experienced by fifth grade students of SD Negeri Mojoarum Gondang Tulungagung 2 class 5 in 2018/2019. The method used in this research is a qualitative descriptive approach. The results of this study are 7 students who have fulfilled all the requirements for questioning skills indicators, on the other hand there is one student who only reaches one point from the requirements, two questioning skills indicator requirements are met by 6 students, there are two students who cannot meet the indicator requirements questioning skills. The obstacles experienced by students have not been able to use Indonesian correctly, lack of focus in asking questions, lack of confidence, fear of being wrong, embarrassed when laughed at by their friends and unable to raise their voices so that questions can reach the whole class. The conclusion of this study is that each student in class $V$ Mojoarum has different questioning skills.
\end{abstract}

Keywords: Student Skills, Thematic, Question and Answer

\begin{abstract}
Abstrak
Tanya jawab adalah bagian utama dari kegiatan belajar siswa. Aktivitas mempertanyakan adalah mengajukan pertanyaan faktual atau hipotesis yang dimulai dengan bimbingan dari guru sampai siswa memahami diri mereka sendiri dan menjadi kegiatan kebiasaan. Penelitian ini bertujuan untuk mendeskripsikan Keterampilan Bertanya Siswa di Lingkungan adalah Tema Teman Kita Sub Subtema Konservasi Lingkungan Subjek Tematik dan menggambarkan hambatan yang dialami siswa kelas V SD Negeri Mojoarum Gondang Tulungagung 2 kelas 5 tahun 2018/2019. Metode yang digunakan dalam penelitian ini adalah pendekatan deskriptif kualitatif. Hasil dari penelitian ini adalah terdapat 7 siswa yang telah memenuhi semua persyaratan indikator keterampilan bertanya, di sisi lain ada satu siswa yang hanya mencapai satu poin dari persyaratan, dua persyaratan indikator keterampilan bertanya dipenuhi oleh 6 siswa, ada dua siswa yang tidak dapat memenuhi persyaratan indikator keterampilan bertanya. Rintangan yang dialami siswa belum dapat menggunakan bahasa Indonesia dengan benar, kurang fokus dalam bertanya, kurang percaya diri, takut salah, malu ketika ditertawakan oleh teman mereka dan tidak mampu mengangkat suara sehingga pertanyaan dapat menjangkau seluruh kelas. Kesimpulan dari penelitian ini adalah setiap siswa siswa kelas V Mojoarum memiliki keterampilan bertanya yang berbeda.
\end{abstract}

Kata kunci: Keterampilan Siswa, Tematik, Tanya Jawab

\section{PENDAHULUAN}

Aktivitas belajar siswa yang tidak lepas dalam kegiatan pembelajaran salah satunya yaitu kegiatan 'menanya' (Questioning).
Kegiatan menanya merupakan kegiatan mengajukan pertanyaan dari yang faktual hingga bersifat hipotesis yang diawali dengan bimbingan guru sampai dengan mandiri atau 
menjadi suatu kebiasaan. "Aktivitas menanya siswa dimaksudkan untuk meningkatkan keingintahuan dalam diri siswa dan mengembangkan kemampuan mereka untuk belajar sepanjang hayat". (Sani, 2014, hal. 57)

Seorang siswa harus memiliki kemampuan untuk mengembangkan pengetahuannya. Kemampuan tersebut salah satunya yaitu keterampilan bertanya. Keterampilan bertanya siswa jarang menjadi perhatian, hal itu terbukti masih belum banyak penelitian yang meneliti tentang keterampilan bertanya yang harus dimiliki siswa, penelitian keterampilan yang banyak diteliti diantaranya yaitu keterampilan bertanya guru, dimana keterampilan itu masuk dalam kategori keterampilan dasar yang harus dimiliki seorang guru. Keterampilan bertanya siswa padahal juga menjadi topik penting yang menarik untuk diteliti dalam pembelajaran yang saat ini diterapkan di Indonesia melalui kurikulum 2013 nya.

Kurikulum 2013 menggunakan pembelajaran tematik dengan pendekatan saintifik sebagai acuan dalam kegiatan belajarnya (Sumantri et al 2018). Kegiatan "menanya" dalam pendekatan saintifik menjadi tahapan kedua yang harus dilakukan oleh siswa. Bertanya menjadi suatu kesempatan untuk siswa mengembangkan rasa keingintahuan akan sesuatu hal agar dapat memperoleh informasi yang ingin diperolehnya. Berdasarkan observasi awal di SDN 2 Mojoarum Kecamatan Gondang Kabupaten Tulungagung, peneliti menemukan di kelas $\mathrm{V}$ ada 7 dari 23 siswa yang aktif bertanya namun pertanyaan mereka aneh-aneh sehingga membuat suasana kelas sering menjadi gaduh. Siswa yang telihat pasif atau jarang sekali bertanya kepada guru maupun peneliti saat peneliti praktek mengajar di kelas tersebut ada 2 siswa dari 23 siswa.

Hal itu didukung juga oleh hasil penelitian yang telah dilakukan oleh Dwi ana Lestari (2015) yang menunjukkan bahwa siswa terlihat secara aktif, bersemangat, dan gembira dalam belajar dan keterampilan bertanya siswa dalam pembelajaran mengalami peningkatan dari 70\% menjadi 77 $\%$. Siswa menurutnya yang pada awalnya pasif, mulai berani mengajukan pertanyaan dan mengeluarkan pendapatnya dalam diskusi kelompok maupun diskusi kelas. Berdasarkan hasil penelitiannya itu, ia menyimpulkan bahwa penerapan pendekatan ilmiah (saintifik) dapat meningkatkan keterampilan bertanya siswa yang akan berpengaruh terhadap peningkatan hasil belajar siswa.

Rumusan masalah dalam penelitian ini yaitu bagaimana keterampilan bertanya siswa 
kelas V mata pelajaran tematik Tema Lingkungan Sahabat Kita Subtema Usaha Pelestarian Lingkungan dan apa saja hambatan yang dialami siswa dalam keterampilan bertanya pada mata pelajaran tematik Tema Lingkungan Sahabat Kita Subtema Usaha Pelestarian Lingkungan kelas V SDN 2 Mojoarum.

Tujuan dari penelitian ini adalah untuk mendeskripsikan keterampilan bertanya siswa dan hambatan yang dialami siswa dalam keterampilan bertanya siswa kelas $\mathrm{V}$ pada matapelajaran tematik Tema Lingkungan Sahabat Kita Subtema Usaha Pelestarian Lingkungan SDN 2 Mojoarum Kecamatan Gondang Kabupaten Tulungagung tahun pelajran 2018/2019.

Manfaat dari penelitian ini secara teoritis yaitu diharapkan dapat menambah pengetahuan tentang keterampilan bertanya siswa. Manfaat praktis bagi peneliti adalah diharapkan dapat menggali dan menambah wawasan serta penegetahuan mengenai keterampilan bertanya siswa. Bagi siswa diharapkan dapat memberi masukan bagi siswa bahwa keterampilan bertanya harus dimiliki siswa untuk dapat mengembangkan rasa ingin tahu dan juga pengetahuan yang akan didapatkan dari kegiatan bertanya tersebut. Bagi guru penelitian ini diharapkan mampu memberikan masukan bagi guru agar dapat memacu siswa untuk lebih percaya diri dan lebih aktif untuk bertanya agar tujuan pembelajaran dapat diperoleh secara optimal. Bagi sekolah, penelitian ini diharapkan dapat menjadi bahan pengembangan bagi pihak sekolah untuk lebih memperhatikan metode mengajar guna meningkatkan keterampilan bertanya siswa agar aktif dalam kegiatan pembelajaran. Bagi peneliti selanjutnya, diharapkan penelitian ini dapat menjadi acuan untuk melakukan penelitian pengembangan selanjutnya.

Belajar sebenarnya tidak lepas dari yang namanya bertanya. Belajar adalah bertanya, karena belajar adalah mencari sesuatu yang belum diketahui. Terdapat pepatah yang mengatakan bahwa "Lebih bertanya dari pada sesat dijalan" sehingga bertanya memiliki peranan penting dalam kehidupan sehari-hari. Bertanya dalam Kamus Besar Bahasa Indonesia adalah meminta keterangan atau penjelasan supaya diberi tahu. Bertanya menurut Brown seperti dikutip Saud (2009) adalah setiap pertanyaan yang mengkaji atau menciptakan ilmu pada diri siswa. Siswa yang aktif bertanya diharapkan memiliki kompetensi untuk mengembangkan kreativitas, rasa ingin tahu mereka dan kemampuan dalam merumuskan pertanyaan yang membentuk pemikiran mereka menjadi lebih kritis terhadap suatu topik maupun permasalahan. 
Siswa dapat bertanya tidak hanya dengan guru maupun temannya, siswa dapat bertanya dengan orang lain untuk mendapatkan informasi yang sesuai dengan apa yang diharapkannya. "Bertanya pada semua aktivitas belajar dilakukan antara siswa dengan siswa, antara guru dengan siswa, dan antara siswa dengan guru, antara siswa dengan orang lain yang didatangkan ke kelas.” (Sagala, 2013). Siswa misalnya mengadakan wawancara dengan kepala desa atau ketua RT di daerah tempat tinggalnya tentang kegiatan kebersihan di lingkungannya. Siswa akan berlatih untuk bertanya dengan baik yang dibimbing oleh gurunya sehingga siswa mampu mendapatkan informasi tentang kegiatan yang ada didaerah tempat tinggalnya untuk menjaga kebersihan lingkungan.

Bertanya merupakan strategi utama yang berbasis kontekstual. Bagi guru bertanya dalam proses pembelajaran adalah kegiatan mendorong, membimbing, dan menilai kemampuan berfikir siswa. Bagi siswa, bertanya adalah kegiatan untuk menggali informasi, mengkonfirmasi apa yang sudah di ketahui dan mengarahkan perhatian pada aspek yang dipahami atau belum diketahui (Trianto, 2013).

Bertanya memiliki banyak fungsi dalam pembelajaran. Hosnan (2016) menyebutkan sebagai berikut.Fungsi bertanya dalam kegiatan pembelajaran diantaranya yaitu: (1) Membangkitkan rasa ingin tahu, minat, dan perhatian siswa tentang tema atau topik pembelajaran. (2) Mendorong dan menginspirasi siswa untuk aktif belajar, serta mengembangkan pertanyaan dai dan untuk dirinya sendiri. (3) Mendiagnosis kesulitan belajar siswa sekaligus menyampaikan rancangan untuk mencapai solusi. Menstrukturkan tugas-tugas dan memberikan kesempatan pada siswa untuk menunjukkan sikap, keterampilan, dan pemahaman atas subtansi pembelajaran yang diberikan. (5) Membangkitkan keterampilan siswa dalam berdiskusi, berargumen, mengembangkan kemampuan berpikir, dan menarik kesimpulan. (6) Membangun sikap keterbukaan untuk saling memberi dan menerima pendapat atau gagasan, memperkaya kosa kata, serta mengembangkan toleransi sosial dalam dalam hidup berkelompok. (7) Membiasakan siswa berpikir spontan dan cepat, serta sigap dalam merespon persoalan yang tiba-tiba muncul. (8) Melatih kesantunan dalam berbicara dan membangkitkan kemampuan berempati satu sama lain.

Bertanya selain memiliki fungsi juga memiliki manfaat. Manfaat kegiatan bertanya menurut Sagala (2013) Fanny, (2019) adalah: (1)menggali infomasi; (2) mengecek pemahaman siswa; (3) membangkitkan 
respon siswa; (4) mengetahui sejauh mana keingintahuan siswa; (5) mengetahui hal-hal yang sudah diketahui siswa;

memfokuskan perhatian siswa pada sesuatu yang dikehendaki guru; (7) untuk membangkitkan lebih banyak lagi pertanyaan dari siswa; (8) untuk menyegarkan kembali pengetahuan siswa.

Penelitian ini menggunakan indikator untuk keterampilan bertanya yang diadaptasi dari Hosnan (2016, hal. 51) tentang kriteria pertanyaan yang baik sebagai berikut:

1) Singkat dan Jelas

Pertanyaan yang diajukan hendaknya bersifat ringkas dan mudah dipahami. Pertanyaan yang berbelit-belit akan membuat orang lain kebingungan sebaliknya jika pertanyaan tersebut ringkas maka akan membuat orang lain dengan mudah memahami maksud dari pertanyaan tersebut. Kejelasan suara juga diperlukan untuk bertanya, hal itu dikarenakan agar pertanyaan dapat tersampaikan dengan baik pada telinga pendengarnya. Pertanyaan yang baik juga perlu menggunakan bahasa Indonesia yang baik dan benar, hal itu untuk melatih siswa berbahasa yang baik agar mudah dipahami.

2) Memiliki fokus

Pertanyaan yang baik harus sesuai dengan topik bahasan dan sesuai dengan yang ingin ditanyakan serta tujuannya. Jika pertanyaan yang diungkapkan tidak memiliki fokus maka tidak akan diperoleh informasi atau tidak dapat menjawab topik permasalahan yang sedang diungkap.

3) Bersifat probing atau divergen

Istilah probing memiliki arti berusaha memperoleh keterangan lebih jelas atau lebih mendalam. Sedangkan divergen memiliki arti kata “ berbeda”. Kaitannya dalam hal ini adalah pertanyaan yang di ajukan harus bervariasi dan memiliki arti yan jelas dan dalam (Nofika, 2019).

Keterampilan bertanya harus dimiliki siswa yang saat ini menjadi pusat perhatian dalam kurikulum 2013 dengan pendekatan saintifiknya, menuntut siswa harus lebih aktif lagi untuk menggali informasi yang ingin mereka tahu baik itu dengan antar siswa, dengan guru maupun dengan lingkungan sekitarnya. Hosnan (2016, hal. 49) memprediksi bahwa "masih banyak siswa belum secara aktif bertanya dalam proses pembelajaran”. Menurutnya ada beberapa hal yang menyebabkan siswa kurang berani untuk bertanya dikarenakan: “(1) siswa merasa dirinya tidak lebih tau dari guru, sebagai akibat dari kebiasaan belajar satu arah; (2) adanya ganjalan psikologis karena guru lebih dewasa dari pada siswa; (3) kurangnya kreatifitas guru untul mengajukan 
persoalan-persoalan yang menantang siswa untuk bertanya".

\section{METODE}

Jenis penelitian yang digunakan oleh peneliti pada penelitian ini adalah jenis deskriptif kualitatif yang mempelajari tentang masalah yang akan diteliti. Penelitian deskriptif kualitatif memasukkan deskripsi terperinci tentang orang dan tempat untuk membawakan naratifnya. (Creswell, 2015). Pendekatan yang digunakan dalam penelitian ini adalah pendekatan deskriptif kualitatif dimana dalam penelitian ini lebih menekankan proses daripada hasil. Pendekatan kualitatif menurut Creswell (2015) adalah pendekatan penelitian yang berguna untuk mengeksplorasi dan memahami fenomena sentral, untuk mempelajarinya peneliti menanyakan pertanyaan-pertanyaan umum dan luas kepada subjek penelitian, mengumpulkan pandangan terperinci subjek dalam bentuk kata-kata atau gambar dimana struktur final laporan penelitian bersifat fleksibel dan memperlihatkan pikiran peneliti.

Subjek pada penelitian ini adalah siswa kelas V SDN 2 Mojoarum yang berjumlah 18 siswa yang terdiri dari 9 siswa laki-laki dan 9 siswa perempuan. Mata pelajaran yang digunakan adalah Tematik pada Tema
8 yaitu Tema Lingkungan Sahabat Kita dengan subtema 3 yaitu Usaha Pelestarian Lingkungan. Pelaksanaan penelitian ini dilaksanakan pada Aril 2019 di SDN 2 Mojoarum.

Instrumen pada penelitian ini terdiri dari dua yaitu peneliti sebagai instrumen utama dan dan intrumen pendukung berupa lembar observasi dan lembar wawancara siswa dan guru.

Teknik pengumpulan data yang digunakan peneliti menggunakan tiga teknik yaitu:

1. Observasi

2. Wawancara

3. Dokumentasi

Analisis data yang dilakukan peneliti menggunakan analisis yang dikemukakan oleh Sugiono (2015) yaitu,

1. Reduksi data

2. Penyajian data

3. Verifikasi data (penarikan kesimpulan).

Dan untuk pengecekan keabsahan data menggunkan tahapan triangulasi dan pemeriksaan dengan dosen dan guru melalui diskusi.

\section{HASIL DAN PEMBAHASAN}

\section{Hasil}

Berikut merupakan beberapa uraian dari hasil observasi dan wawancara yang 
telah dilakukan peneliti dengan siswa pada tanggal 18 April 2019 dan 20 April 2019 di kelas V yaitu sebagai berikut:

\section{1) Nama \\ : AD \\ Jenis Kelamin : Laki-Laki \\ Deskripsi}

AD merupakan siswa yang aktif dikelas.AD mampu bertanya dengan singkat dan jelas tanpa berbelit-belit. Saat bertanya suara $\mathrm{AD}$ mampu menjangkau isi ruang kelas. Meski pertanyaan yang ia ajukan singkat dan jelas akan tetapi pertanyaannya tidak memiliki fokus. Dia bertanya untuk memancing keriuhan di kelas. Bentuk pertanyaan $\mathrm{AD}$ yaitu "Lha lek ninglaut akeh sampah mosok yo arep di saponi?”. Berdasarkan pertanyaan $\mathrm{AD}$ tersebut terlihat jika pertanyaan itu tidak bersifat menggali informasi lebih dalam meskipun pertanyaannya bervariasi. Bahasa yang ia gunakan untuk bertanya yaitu bahasa Jawa. Berdasarkan hasil wawancara ia mengungkapkan jika ia lebih sering menggunakan bahasa Jawa dibandingkan dengan Bahasa Indonesia. Respon guru saat siswa bertanya menggunakan bahasa Jawa tidak masalah.

2) Nama : NL

Jenis Kelamin : Perempuan

Deskripsi :

NL merupakan siswa yang pendiam. Dia tidak terlihat aktif seperti teman-teman yang lainnya. Saat teman-temannya riuh riang tertawa ia hanya terlihat ikut tersenyum saja. NL tidak melontarkan pertanyaan saat penelitimelakukan observasi selama pembelajaran tema lingkungan sahabat kita subtema usaha pelestarian lingkungan. Terlihat ia tampak malu-malu saat berbicara dengan teman-temannya. Ternyata hal itu juga selaras dengan hasilwawancara yang peneliti lakukan dengan NL, peneliti ingin lebih banyak menggali informasi kenapa ia tidak bertanya saat pembelajaran berlangsung.hasil wawancara peneliti dengan NL tentang tanggapan temantemannya saat ia bertanya namun suaranya tidak dapat menjangkau isi ruang kelas. "Diteriaki agar saya mengulangi lagi bu." Berdasarkan jawaban tersebut peneliti juga menggali informasi tentang bagaimana biasanya tanggapan guru saat seperti itu. Berikut jawaban NL: “ Kadang di dekati dan diminta untuk mengulangi itu". Berdasarkan hal itu dapat di ketahui bahwa guru juga menaruh perhatian dan juga memberikan pengarahan kepada siswa agar keterampilan bertanya dapat terlaksana dengan baik sesuai yang harapkan. Selain itu, informasi lain yang didapatkan peneliti dari hasil wawancara dengan NL bahwa NL merasa malu saat ditunjuk guru untuk bertanya, ia malu jika pertanyaan yang ia lobntarkan salah dan di tertawakan oleh temna- 
temannya. NL juga pernah merasa kebingungan karena pertanyaan yang ingin disampaikan oleh NL sudah ditanyakan oleh temn-temanya. Untuk hasil observasi dan wawancara secara lengkap dengan NL dapat dilihat pada lampiran.

\section{3) Nama : NN}

\section{Jenis Kelamin : Perempuan}

Deskripsi :

NN merupakan siswa yang pemalu. Ia di hampiri guru untuk mengulangi pertanyaan yang ia ajukan. Bentuk pertanyaan NN yaitu sebagi berikut "Bagaimana cara mengolah limbah agar tidak mencemari lingkungan?". Berdasarkan pertanyaan tersebut dapat diketahui jika bentuk pertanyaan NN meupakan pertanyaan yang singkat dan jelas, memiliki fokus, bervariasi dan bersifat mendalam. Namun kendalanya, ia memiliki suara yang lembut sehingga saat bertanya pertanyaan tersebut harus diulanginya hingga beberapa kali agar teman-teman maupun guru dapat mendengar pertanyaan tersebut. Hal itu ternyata didukung berdasarkan hasil wawancara peneliti dengan $\mathrm{NN}$ tentang perasannya saat diminta untuk mengulangi pertanyaan. "Saya gugup bu. saya malu dan takut salah. Biasanya saya di tertawakan oleh teman-teman". Berdasarkan hasil wawancara tersebut ternyata NN tidak bisa memaksimalkan suaranya karena memang suara yang dimilikinya lembut dan ia merupakan siwa yang pemalu. Untuk hasil observasi dan wawancara secara lengkap dengan $\mathrm{NN}$ dapat dilihat pada lampiran.
4) Nama : AM
Jenis Kelamin : Perempuan
Deskripsi :

AM merupakan siswa yang pendiam. Ia tidak bertanya pada saat kegiatan pembelajaran berlangsung. Berdasarkan hasil wawancara peneliti dengan AM tentang apa yang membuat AM tidak bertanya yaitu ia takut dan malu untuk bertanya.

Simpulan dari hasil observasi seperti di atas pada penelitian ini dapat diketahui bahwa semua siswa memiliki kemampuan akan keterampilan bertanya yang berbeda beda. Siswa yang mampu memenuhi semua indikator keterampilan bertanya sebanyak 7 siswa diantaranya yaitu AN, IL, LA, STR, TT, DV, dan PT. Untuk siswa yang dapat memenuhi satu indikator keterampilan bertanya sebanya 3 siswa yaitu FK, RF, dan BST. Untuk Siswa yang mampu memenuhi dua indikator keterampilan bertanya sebanyak 6 siswa, diantaranya yaitu AD, EK, RO, AK, dan NN. Sedangkan untuk siswa yang sama sekali belum mampu memenuhi indikator keterampilan bertanya ada 2 siswa yaitu AM dan NL. 
Hambatan yang dihadapi siswa dalam keterampilan bertanya berdasarkan hasil observasi siswa yang mampu menggunakan bahasa Indonesia dengan baik dan benar sebanyak 4 anak. Yaitu AN, IL, STR dan TT, sedangkan untuk 14 siswa lain menggunakan bahasa campuran yaitu bahasa Jawa dan bahasa Indonesia.

Siswa saat bertanya tentu membutuhkan energi suara yang cukup untuk menjangkau seluruh ruangan kelas agar pertanyaan dapat tersampaikan dengan baik. Siswa yang memiliki suara yang lembut sebanyak 3 siswa, sehingga saat melontarkan pertanyaan ia diminta untuk mengulangi pertanyaan tersebut. Sesuai dengan hasil observasi yang peneliti lakukan ketiga siswa yang memiliki suara yang lembut yaitu AM, NL, dan NN.

Saat siswa diberikan kesempatan untuk bertanya oleh guru namun tidak ada siswa yang bertanya maka guru menunjuk langsung siswa secara acak. Perasaan merekapun juga beraneka ragam, ada yang merasa gugup, malu, dan juga senang saat di tunjuk untuk bertanya.

Siswa terkadang bertanya tidak sesuai topik pelajaran sehingga menjadi bahan bercandaan yang membuat suasana menjadi ramai di dalam kelas. Bapak Suyanto, S.Pd. beberapa kali memberikan teguran kepada siswa agar suasana kelas dapat menjadi kondusif kembali saat ada teman yang melontarkan pertanyan yang tidak sesuai dengan topik pelajaran.

\section{Pembahasan}

Keterampilan bertanya yang baik dilihat dari indikator keterampilan bertanya menurut Hosnan (2016) yaitu pertanyaan yang baik itu meliputi tiga hal sebagai beriku: a) singkat dan jelas, b) memiliki fokus), dan c)bersifat probing dan divergen. Dari ketiga indikator tersebut yang telah di kembangkan peneliti kedalam berbagai pernyataan menunjukkan bahwa semua siswa memiliki kemampuan akan keterampilan bertanya yang berbeda beda. Siswa yang mampu memenuhi semua indikator keterampilan bertanya sebanyak 7 siswa diantaranya yaitu AN, IL, LA, STR, TT, DV, dan PT. Untuk siswa yang dapat memenuhi satu indikator keterampilan bertanya yaitu FK, RF, dan BST. Untuk Siswa yang mampu memenuhi dua indikator keterampilan bertanya sebanyak 6 siswa, diantaranya yaitu AD, EK, RO, AK, dan NN. Sedangkan untuk siswa yang sama sekali belum mampu memenuhi indikator keterampilan bertanya ada 2 siswa yaitu AM dan NL.

Berdasarkan hasil observasi, wawancara dengan siswa dan wawancara dengan guru yang telah diuraikan dapat diketahui jika sebagian besar siswa telah mampu bertanya 
dengan bahasa yang singkat dan jelas namun bahasa yang siswa gunakan masih belum sesuai. Siswa menggunakan bahasa seharihari (Bahasa Jawa) yang di campur dengan Bahasa Indonesia. Untuk indikator keterampilan bertanya yaitu saat saat bertanya harus memiliki fokus, siswa belum cukup mampu karena mereka terkadang masih bertanya keluar dari topik pembahasan yang di selingi dengan bercanda. Sedangkan untuk indikator bersifat probing dan divergen siswa telah mampu untuk memvariasikan pertanyaan sesuai dengan kebutuhan pengetahuan yang ingin mereka dapatkan dengan menggunakan kata tanya apa, siapa, dimana, mengapa, kapan dan bagaimana.

Dua siswa tidak bertanya pada kegitan pembelajaran. ia mengalami hambatan dalam keterampilan bertanya yaitu ia merasa bingung mau bertanya apa dan malu untuk bertanya. Dua siswa tersebut adalah AM dan NL. Dari hal tersebut tebukti jika di kaitkan dengan hasil teori Hosnan (2016, hal. 49) yang memprediksi bahwa "masih banyak siswa belum secara aktif bertanya dalam proses pembelajaran". Menurutnya ada beberapa hal yang menyebabkan siswa kurang berani untuk bertanya dikarenakan: (1) siswa merasa dirinya tidak lebih tau dari guru, sebagai akibat dari kebiasaan belajar satu arah; (2) adanya ganjalan psikologis karena guru lebih dewasa dari pada siswa; (3) kurangnya kreatifitas guru untul mengajukan persoalan-persoalan yang menantang siswa untuk bertanya.

\section{KESIMPULAN}

Berdasarkan hasil penelitian yang telah dilakukan pada siswa kelas V SDN 2 Mojoarum, dapat diambil kesimpulan bahwa semua siswa memiliki kemampuan akan keterampilan bertanya yang berbeda beda. Siswa yang mampu memenuhi semua indikator keterampilan bertanya sebanyak 7 siswa. Siswa yang mampu memenuhi satu indikator keterampilan bertanya sebanyak 1 siswa. Untuk Siswa yang mampu memenuhi dua indikator keterampilan bertanya sebanyak 6 siswa. Sedangkan untuk siswa yang sama sekali belum mampu memenuhi indikator keterampilan bertanya ada 2 siswa.

Hambatan yang dialami siswa dalam keterampilan bertanya meliputi siswa belum mampu dalam menggunakan bahasa Indonesia secara baik dan benar, siswa kurang dapat memiliki fokus dalam bertanya, rasa malu saat akan bertanya, takut salah, malu jika tertawakan teman, dan kurang dapat memaksimalkan suara yang di miliki sehingga suara tidak dapat menjangkau seluruh isi kelas.

\section{DAFTAR PUSTAKA}


Creswell, J. (2015). Riset Pendidikan; Perencanaan, Pelaksanaan, dan EvaluasiRiset Kualitatif dan Kuantitatif . Yogyakarta: Pustaka Pelajar

Hosnan. (2016). Pendekatan Saintifik dan Kontekstual dalam Pembelajaran Abad 21(ed. 2). Jakarta: Ghalia Indonesia

Lestari, D. A. (2015). Pendekatan Saintifik dalam Pembelajaran Tematik untuk Meningkatkan Keterampilan Bertanya Siswa. Widyagogik 3(1), 6678

Nofika, M. (2019). Pengembangan Keterampilan Bertanya Siswa dalam Pembelajaran tentang Vektor Menggunakan Model Pembelajaran Problem Composing. In Skripsi. Yogyakarta: Prodi Fisika Universitas Sanata Dharma.

Sagala, S. (2013). Konsep dan Makna Pembelajaran: Untuk Membantu Memecahkan Problematika Belajar Mengajar. Bandung: Alfabeta.

Sani, R. A. (2014). Pembelajaran Saintifik untuk Implementasi Kurikulum 2013. Jakarta: Bumi Aksara.

Saud, U. S. (Ed.). (2009). Pengembangan Profesi Guru. Bandung: Alfabeta.
Sugiono. (2015). Metode Penelitian Pendidikan; Pendekatan Kuantitatif, Kualitatifdan $R \& D . \quad$ Bandung: Alfabeta

Sumantri, M. S., Prayuningtyas, A. W., Rachmadtullah, R., \& Magdalena, I. (2018). The Roles of TeacherTraining Programs and Student Teachers' Self-Regulation in Developing Competence in Teaching Science. Advanced Science Letters, 24(10), 7077-7081.

Trianto. (2013). Mendesain Model Pembelajaran Inovatif-Progresif: Konsep, Landasan dan Implementasi pada Kurikulum Tingkat Satuan Pendidika (KTSP) (ed. 6). Jakarta: Kencana Prenadamedia Group

Fanny, A. M. (2019, March). Analysis Of Pedagogical Skills And Readiness Of Elementary School Teachers In Support Of The Implementation Of The $2013 \quad$ Curriculum. In International Conference on Bussiness Law and Pedagogy (Vol. 1, No. 1, pp. 59-63). 
